\title{
APLIKASI METODE (QFD) UNTUK MENINGKATKAN KUALITAS LAYANAN PERMOHONAN SIM PADA SATLANTAS KABUPATEN JOMBANG
}

\author{
Sri Nugrahani \\ nugrahani73@gmail.com \\ Rukmi Budirahaju \\ Universitas Darul Ulum Jombang
}

\begin{abstract}
This study aims to knowing and analyze the quality of service and quality of service process factors prioritized based on the level of importance and satisfaction of applicants SIM (Driving License) provided by SATLANTAS (Traffic Police Unit) Kab. Jombang. This type of research is a case study, using a qualitative approach. The population of the SIM (Driving License) seekers with 120 informants. Analytical technique Function Deployment. The results of this research are nine (9) Attributes that are considered important and able to make the SIM (Driving License) seekers are satisfied and important. These attributes are the service of the SIM (Driving License) making form, the physical health test service, the practice test material is equipped with traffic signs, The availability of panel boards to automatically determine the pass rates in each of the practical exam stages, the availability of test vehicles and mental health test services, the knowledge of traffic signs and the variety of practice test terrain. Based on the relation matrix analysis of the contribution of technical response, the greater the influence of the technical response to the performance of customer satisfaction, the more important the technical response is to be implemented as well as possible.
\end{abstract}

Key words: QFD, interest, satisfaction SIM (Driving License) Seekers

\begin{abstract}
ABSTRAK
Penelitian ini bertujuan untuk mengetahui dan menganalisis kualitas layanan jasa dan faktor-faktor proses kualitas pelayanan jasa yang diprioritaskan berdasarkan tingkat kepentingan dan kepuasan pemohon SIM yang diberikan oleh SATLANTAS Kabupaten Jombang. Jenis penelitian ini merupakan studi kasus, dengan menggunakan pendekatan kualitatif. Populasinya para pencari SIM dengan 120 informan. Teknik analisis yang digunakan Quality Function Deployment. Hasil penelitian ini terdapat sembilan (9) atribut yang dianggap penting dan mampu membuat masyarakat pencari SIM puas dan penting. Atribut tersebut adalah pelayanan formulir pembuatan SIM, pelayanan tes kesehatan fisik, materi tes praktek dilengkapi tanda-tanda lalu lintas, pengetlahuan tentang syarat perpindahan jalur, ketersediaan papan panel untuk menentukan secara otomatis tingkat kelulusan dalam setiap tahapan ujian praktek, ketersediaan kendaraan untuk tes dan pelayanan tes kesehatan mental, pengetahuan tentang rambu-rambu lalu lintas dan variasi medan tes praktek. Berdasarkan analisa relation matrix kontribusi respon teknis, semakin besar pengaruh respon teknis tersebut terhadap performansi kepuasan pelanggan, maka semakin penting respon teknis ini untuk dilaksanakan sebaik-baiknya.
\end{abstract}

Kata kunci : QFD, kepentingan, kepuasan pencari SIM

\section{PENDAHULUAN}

Aplikasi konsep kualitas dalam suatu lembaga milik pemerintah dalam hal ini adalah SATLANTAS diharapkan masyarakat benar-benar mempunyai kesadaran dan kompetensi yang maksimal serta tingkat kedisiplinan yang tinggi sehingga angka kecelakaan dapat diminimalisir. Bagi masyarakat yang mengerti betul terhadap peraturan berlalu lintas akan menjaga dan menghormati sesama pengguna jalan sehingga tercipta kesopanan dan tertib berlalu lintas. Nilai tambah bagi konsumen adalah ketika pelayanan jasa ditingkatkan, sehingga 
tidak hanya ilmu pengetahuan dan kemampuannya yang konsumen dapatkan, peningkatan intektual dan juga kecerdasannya (Hwarng dan Teo, 2001). Penilaian positif terhadap beberapa dimensi fasilitas publik diantaranya adalah: tampilan fisik (Arief, 2011).

Pada awalnya QFD diciptakan untuk membantu proses pendesainan produk baru sesuai dengan kebutuhan dan keinginan pelanggan. Dalam perkembangan saat ini, QFD tidak hanya digunakan untuk mendesain produk baru, tetapi dapat juga diterapkan untuk berbagai proses pengembangan produk maupun jasa yang sudah ada, (Irawan dan Iqsan, 2012). Perencanaan kurikulum sekolah, hot line service centers, software, computer dan sebagainya saat ini juga menggunakan QFD (Cohen, 1995). Kualitas pelayanan dalam menawarkan produk dan jasa merupakan prioritas utama karena hal ini mencerminkan kinerja perusahaan (Chevri dan Iskandar, 2015). Penilaian pelanggan secara positif maupun negatif pada semua atribut yang dinilai merupakan langkah pasti yang harus ditempuh oleh pihak pengelola (Yulianti dan Soenandi, 2014). QFD bisa dianalogikan sebagai suatu matriks berbentuk rumah yang disebut rumah kualitas (house of quality). Rumah kualitas digunakan untuk memahami the voice of customer atau suara pelanggan dan diterjemahkan ke dalam the voice the engineer atau suara perekayasa perusahaan (Djunaidi et al., 2006). QFD merupakan model integrasi sebagai metode penghematan biaya yang mampu menjembatani kebutuhan konsumen dengan kemampuan perusahaan (Singgih et al., 2014).

Pentingnya konsep kualitas dalam proses permohonan SIM ditambah dengan petugas yang berpengalaman dan profesional maka para pengelola atau jajaran manajemen dalam SATLANTAS harus mengontrol pelaksanaan proses permohonan SIM. Proses permohonan SIM dalam penelitian ini diasumsikan sebagai product features pendidikan yang terfokus dalam keterampilan maupun ketaatan peraturan berlalu lintas, seperti materi ujian teori dan praktek, cara menilai tingkat kelulusan ujian, petugas, fasilitas yang digunakan dalam proses permohonan SIM dan sebagainya. Faktor tersebut harus diperhatikan dan dibenahi untuk meningkatkan kualitas layanan jasa pihak SATLANTAS.

Berdasarkan uraian di atas dan rumusan masalah dari penelitian ini maka tujuan yang hendak dicapai adalah: (a) mengetahui dan menganalisis kualitas layanan jasa yang diberikan oleh SATLANTAS Kabupaten Jombang secara optimal sesuai dengan keinginan dan kepuasan pemohon SIM. (b) mengetahui dan menganalisis faktor-faktor proses kualitas pelayanan jasa yang diprioritaskan berdasarkan tingkat kepentingan pemohon SIM.

Adapun manfaat dari hasil penelitian ini antara lain: (a) memberikan sumbangan pemikiran kepada pihak Manajemen SATLANTAS Kabupaten Jombang mengenai penerapan konsep kualitas layanan jasa dalam pelaksanaan proses permohonan SIM yang sesuai dengan kebutuhan dan keinginan pemohon SIM beserta sumber daya yang dimilikinya mengingat masyarakat yang dilayani sangat variatif. (b) memberikan kontribusi informasi mengenai ketidakpuasan masyarakat yang disebabkan oleh kegagalan pelayanan. Serta memberikan gambaran mengenai berbagai keragaman dari bentuk pelayanan yang dianggap kurang memadai. (c) hasil memberikan kontribusi informasi mengenai titik-titik lemah dalam sistem setting proses pelayanan permohonan SIM, sehingga para pihak manajemen SATLANTAS Kabupaten Jombang tersebut dapat membenahi dan meningkatkan kinerja sistem mereka. (d) memberikan kontribusi potensial kepada para pembaca mengenai ilmu manajemen pemasaran, khususnya berkaitan dengan customer relationship management (CRM) dan kualitas pelayanan jasa. (e) hasil penellitian dapat dijadikan pengayaan bahan ajar sebagai kajian perbandingan antara studi empiris dan teoretis sehingga masyarakat lebih paham teori kualitas pelayanan. 


\section{TINJAUAN TEORETIS \\ Pemasaran Jasa}

Sejumlah ahli merumuskan definisi jasa yang beragam. Kotler dan Keller (2012) menyatakan bahwa jasa merupakan setiap aktifitas, manfaat atau performance yang ditawarkan oleh satu pihak ke pihak lain yang bersifat intangible dan tidak menyebabkan perpindahan kepemilikan apapun di mana dalam produksinya dapat terikat maupun tidak dengan produk fisik. Tjiptono (2014: 26) mengemukakan bahwa jasa adalah setiap tindakan atau perbuatan yang dapat ditawarkan oleh suatu pihak lain yang pada dasarnya bersifat intangible (tidak berwujud fisik) dan tidak menghasilkan kepemilikan sesuatu.

Menurut Lovelock dan Gummesson (2011) mendefinisikan bahwa service (pelayanan) adalah sebuah bentuk jasa dimana para pelanggan atau konsumen dapat memperoleh manfaat melalui nilai jasa yang diharapkan. Pelayanan yang cepat dan mudah adalah salah satu bentuk service dalam melayani pelanggan agar loyalitas pelanggan terjaga (Irawan dan Iqsan, 2012). Reward juga bisa memotivasi kayawan untuk berbuat lebih baik dalam service kepada pelanggan (Dharmawan dan Wurjaningrum, 2014). Penanganan keluhan secara responsif (contohnya keamanan, kemudahan ketika komplain) akan memberikan dampak yang positif bagi sebuah usaha (Indriani dan Sari, 2011).

\section{Karakteristik Jasa}

Menurut Kotler dan Keller (2012), ada empat karakteristik jasa yang pertama tidak berwujud (intangible), kedua bervariasi (variability), ketiga tidak dapat dipisahkan (insenparability) dan keempat tidak dapat disimpan (pershability). Karakteristik jasa sangat menentukan opini masyarakat dalam memilih jasa yang akan digunakan, seringkali fasilitas penunjang juga sangat mendukung kondisi jasa yang ditawarkan bahkan fasilitas dijadikan pertimbangan utama yang dipentingkan oleh para pengguna jasa (Patmawan et al., 2015). Penawaran jasa atau produk jika masih terdapat keluhan pelanggan tentang kualitas maka perlu peninjauan terhadap konsumen untuk meningkatkan kualitas jasa atau produk tersebut (Destyasa et al., 2013). Strategi pemasaran terpadu akan mempengaruhi kepuasan pelanggan dan akan berdampak langsung pada keunggulan bersaing dan merupakan ciri khas jasa yang tertanam dalam benak konsumen (Fuad et al., 2012). Produsen produk atau jasa yang akan memenangkan persaingan adalah mereka yang selalu berorientasi untuk memberikan kepuasan kepada pelanggannya (Tampubolon et al., 2013).

\section{Kepuasan dan Ketidakpuasan Pelanggan}

Kepuasan pelanggan menurut Kotler dan Keller (2012) adalah perasaan senang atau kecewa yang muncul setelah membandingkan kinerja (hasil) produk yang dipikirkan terhadap kinerja (hasil) yang diharapkan. Untuk mencapai loyalitas pelanggan hal penting yang perlu dilakukan adalah meningkatkan kepuasan pelanggan (Karna, 2014). Mohsan et al. (2011), kepuasan adalah keseluruhan dari sikap atau perilaku pelanggan terhadap pelayanan yang diberikan, atau sebuah reaksi emosional terhadap perbedaan antara apa yang diharapkan pelanggan dan apa yang mereka terima, mengenai pemenuhan beberapa kebutuhan, keinginan dan tujuan. Perusahaan yang mempunyai kualitas pelayanan lebih dari kualitas pelayanan pesaingnya maka perusahaan tersebut bisa memenangkan persaingan. Ada 2 faktor yang mempengaruhi kualitas pelayanan jasa yaitu expected service dan perceived service. Bila jasa yang diterima atau dirasakan sesuai dengan harapan maka kualitas pelayanan jasa dipersepsikan baik dan memuaskan. Jika jasa yang diterima melampaui harapan pelanggan, maka kualitas pelayanan jasa dipersepsikan sebagai kualitas yang ideal. Sebaliknya jika jasa yang diterima lebih rendah daripada yang diharapkan maka kualitas pelayanan jasa dipersepsikan buruk (Tjiptono, 2014). Pertama jika terjadi diskonfirmasi negatif 
(negative disconfirmation), bila tampilan produk atau jasa yang dirasakan jauh di bawah harapan. Kedua akan terjadi diskonfirmasi positif (positive disconfirmation) bila tampilan yang dirasakan pelanggan melebihi harapan. Dan jika antara kenyataan dan harapan konsumen adalah negatif maka harus diprioritaskan peningkatkan pelayanan untuk dapat memenuhi keinginan dan memberikan kepuasan pada konsumen (Yulianti dan Soenandi, 2014).

Ada berbagai cara pelanggan untuk merespon kegagalan pelayanan. Diam saja, komplain, melapor pada pihak ketiga, komunikasi word-of-mouth yang negatif, dan pergi untuk berganti penyedia jasa merupakan cara pelanggan untuk merespon kegagalan sebuah pelayanan (Lovelock dan Gummesson, 2011). Kemudahan dalam menyampaikan komplain juga merupakan penilaian penting bagi pelanggan (Indriani dan Sari, 2011). Akhirnya kepuasan konsumen/pelanggan adalah hal yang harus diprioritaskan apalagi jika usahanya bergerak dalam bidang jasa, kepuasan konsumen adalah mutlak (Margareta dan Wahyuni, 2016).

Keragaman dari berbagai tipe respon dapat di ilustrasikan pada Tabel 1 sebagai berikut:

Tabel 1

Taksonomi dari Tipe-tipe Respon terhadap Ketidakpuasan

\begin{tabular}{|c|c|c|}
\hline \multicolumn{3}{|c|}{ Towards enitity } \\
\hline Response type & $\begin{array}{l}\text { Public (Sellers. manufacturers, official } \\
\text { organizations, associations, justice) }\end{array}$ & $\begin{array}{l}\text { Private } \\
\text { (Family. friends. } \\
\text { relations.) }\end{array}$ \\
\hline Behavioural & $\begin{array}{l}\text { Complaint } \\
\text { Legal action } \\
\text { Retum of the item Request } \\
\text { for repair }\end{array}$ & $\begin{array}{l}\text { Word of mouth } \\
\text { Boycott/leaving }\end{array}$ \\
\hline Non-behavioural & $\begin{array}{l}\text { No action, with or without } \\
\text { modification of the attitudeForgot or } \\
\text { forgive }\end{array}$ & \\
\hline
\end{tabular}

Sumber: Crie, 2003.

Tabel 1 tersebut sebagian dapat dijelaskan bahwa tipe respon yang disebabkan intensitas dari ketidakpuasan dan oleh sifat dan tingkat kepentingan dari produk atau jasa yang bersangkutan. Konsumen juga dapat menggabungkan atau menghubungkan beberapa tipe respon untuk ketidak puasan yang sama (Crie, 2003). Semakin mahal dan rumit suatu produk, maka, konsumen akan semakin cenderung untuk mengajukan tindakan publik. Loyalitas pelanggan akan terjadi jika kualiatas layanan yang diterima sesuai dengan harapannya (Tjiptono, 2014). Peter et al., (2010) menyatakan bahwa in theory, if consumers are satisfied with a product, service, or brand, they will be more likely to continue to purchase it and tell others about their favorable experience with it.

Hasil penelitian yang menerapkan QFD dapat disimpulkan bahwa produk yang sama dengan sistem penawaran yang berbeda disertai nilai fungsi yang lebih bagi konsumen akan menciptakan fokus perhatian calon pembeli dan akan berpotensi untuk melakukan transaksi (Mutiara et al., 2013).

\section{QFD dalam Meningkatkan Kualitas Laya- nan Lembaga Pemerintah}

Menurut Lijan (2014), pelayanan publik adalah pemenuhan keinginan dan kebutuhan masyarakat oleh penyelenggara negara. 
Kebutuhan dalam hal ini bukanlah kebutuhan secara individual akan tetapi berbagai kebutuhan yang sesungguhnya diharapkan oleh masyarakat, seperti kebutuhan akan kesehatan, pendidikan dan lain-lain. Normalisasi Skala Kepentingan Konsumen (NSKK) harus diutamakan oleh pihak pengelola karena hal ini merupakan cara untuk mempertahankan loyalitas konsumen atau pelanggan (Siwantara, 2011). Pendapat yang berbeda yang menyatakan bahwa pentingnya memperhatikan kondisi saat ini dengan dukungan informasi teknologi akan mendukung kualitas layanan bagi lembaga pemerintah yang sebagian besar belum sepenuhnya menerapkan IT (Suhendar dan Suroto, 2014). Hasil penelitian yang mendasar pada HOQ akan diketahui atribut yang menjadi prioritas technical responses melalui nilai tertinggi dan meningkatkan kualitas pelayanan secara kontinyu, setiap atribut yang mengindikasikan unsur-unsur tersebut akan menjadi fokus kepentingan dan kepuasan pelanggan (Erni et al., 2013).

Aplikasi QFD juga harus memperhatikan potensi lingkungan dan kondisi sosial budaya masyarakat, berdasarkan hasil penelitian yang menyimpulkan bahwa pelayanan institusi pemerintah akan menambah nilai kepuasan yang diperoleh oleh konsumen jika atributnya dipengaruhi oleh nilai-nilai dalam agama khususnya jika kelompok masyarakat tersebut merupakan kelompok minoritas (Susila et al., 2014). Dalam penelitian yang dilakukan oleh Hwarng dan Teo (2001) digunakan konsep Juran's Triple Role seperti Gambar 1 berikut:

OUR ROLE

\begin{tabular}{|c|c|c|c|c|}
\hline Custom & ner & Processor & Supplier & \\
\hline $\begin{array}{l}\text { Out } \\
\text { Supplier }\end{array}$ & 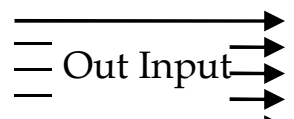 & Our Processor & $\bar{E}$ Out Produk $\longrightarrow$ & $\begin{array}{l}\text { Out } \\
\text { Customer }\end{array}$ \\
\hline
\end{tabular}

\section{Gambar 1 \\ Diagram TRIPPOL}

Sumber: Juran (1982) dalam Hwarng dan Teo (2001)

\section{Quality Function Deployment}

Djunaidi et al. (2006), menyatakan bahwa sebuah bisnis jasa mulai dari penentuan strategi sampai dengan pencapaian tujuan dapat diterapkan dengan konsep QFD, sehingga tidak hanya terbatas pada sebuah produk saja yang bisa menerapkan konsep QFD. Menurut (Cohen, 1995), QFD adalah suatu metode perencanaan dan pengembangan produk atau jasa yang terstruktur yang memungkinkan tim pengembang mendefinisikan keinginan dan kebutuhan pelanggan kemudian mengevaluasi kemampuan dari produk atau jasa yang diusulkan tersebut untuk memenuhi keinginan dan kebutuhan pelanggan.

Rumah kualitas adalah gambaran dari sekumpulan matriks yang saling berinteraksi satu sama lain, seperti yang ditunjukkan pada gambar 2. Gambar 2 dapat memberi informasi mengenai: (1) Kebutuhan pelanggan (customer needs) berupa kebutuhan dan keinginan pelanggan dari sebuah produk atau jasa, (2) Respon teknis (technical response) berupa apa dan bagaimana yang dapat dilakukan oleh perusahaan untuk 


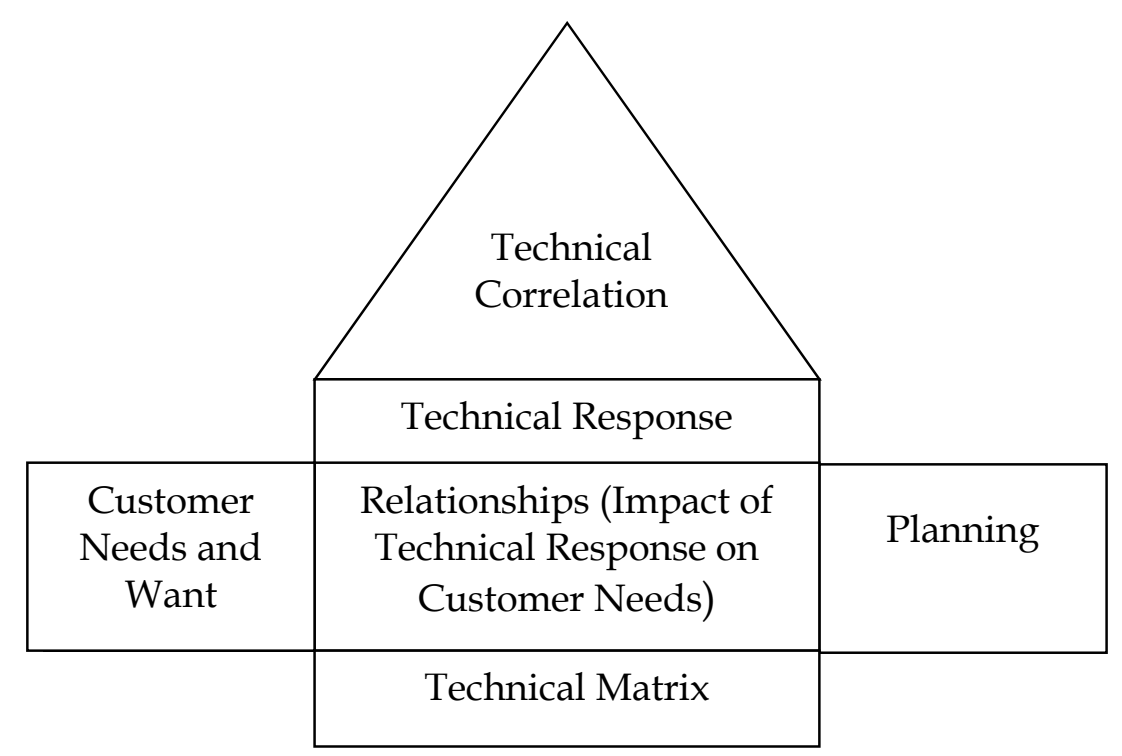

\section{Sumber: Cohen,1995 \\ Rumah Kualitas (HOUSE OF QUALITY)}

memenuhi kebutuhan dan keinginan tersebut, (3) Pengaruh respon teknis pada kebutuhan pelanggan (relationship) berupa pengaruh respon teknis terhadap kepuasan pelanggan, (4) Matrik perencanaan (planning matrix), berupa metode-metode untuk membangun strategi untuk kepuasan pelanggan dan membandingkan produk atau jasa sendiri dalam memenuhi kebutuhan pelanggan dengan pesaingnya, (5) Hubungan antar respon teknis (technical correlations) yaitu pengaruh yang antara respon teknis yang satu dengan yang lain baik pengaruh positif (saling mendukung) ataupun pengaruh negatif (saling berlawanan), (6) Matriks teknis (technical matrix) yang terdiri penentuan respon teknis yang memberi kontribusi besar pada kepuasan pelanggan, penilaian dengan pesaing atau competitive benchmarks serta penentuan target respon teknis dengan berdasarkan performansi respon teknis dari pesaing.

Benjamin et al., (1999) melakukan penelitian aplikasi kerangka kerja QFD untuk perencanaan kurikulum. Penelitian studi kasus ini dilaksanakan pada Sekolah Bisnis dan Industri (SBI) di Florida A \& M University (FAMU) dengan menentukan maha- siswa SBI sebagai pelanggan. Hasil dari penelitian ini adalah mata kuliah manajemen proyek menjadi mata kuliah yang paling dipenting- kan oleh mahasiswa, sedangkan mata kuliah mathematical programming dan value engi-neering menjadi mata kuliah yang paling tidak dipentingkan.

Penelitian yang dilakukan oleh Sulistyo (2011), ada 21 desain teknis dapat digunakan untuk merancang revitalisasi pasar tradisional berbasis kebutuhan konsumen, namun demikian penelitian ini hanya berusaha menemukan target values, namun belum secara detail pada ukuran-ukuran yang sesuai dengan kondisi masing-masing pasar tradisional, sehingga belum bisa di buat prototype desain pasar tradisional yang mampu bersaing dengan pasar modern berbasis QFD.

Arief (2011) melakukan penelitian mengenai kualitas pelayanan publik di bandara Internasional Sultan Hasanuddin Makassar. Hasil analisa data menunjukkan bahwa kualitas pelayanan publik pada Bandara Internasional Sultan Hasanuddin Makassar belum maksimal, dimana penilaian negatif dari penumpang lebih dominan dari penilaian positifnya. Penilaian positif berupa 
tampilan fisik bandara baik dari interior maupun eksterior, penampilan petugas, kesejukan dan kapasitas terminal serta kecukupan jumlah trolley. Begitupun dari kualitas pelayanan dalam bidang keterampilan petugas, kemudahan mendapatkan informasi, kecepatan dalam pelayanan pemeriksaan keamanan serta check in dan kejelasan mengenai prosedur pelayanan. Penilaian negatif berupa penggunaan bandara sebagai sarana promosi dan pemasangan iklan, keandalan sarana dan prasa rana pendukung fasilitas pelayanan publik seperti toilet, perparkiran, dan arus lalu lintas belum memenuhi standar pelayanan, kesopanan dan keramahan petugas dalam menangani masalah yang dihadapi penumpang, kemudahan mendapatkan informasi, layanan bus bandara dan pelayanan non formal yakni calo dan angkutan liar di bandara.

Utami (2015), melakukan penelitian tentang pendekatan model kano pada quality function deployment untuk perbaikan kualitas kegiatan belajar mengajar. Hasilnya, penerapan model kano untuk penentuan voice of customer pada metode quality function deployment (QFD) dilakukan untuk mendapatkan masukan tentang atribut kualitas yang sungguh-sungguh diinginkan oleh pelanggan. Pada penelitian ini, penerapan model Kano telah dapat mengidentifikasi dengan baik keinginan pengguna Sistem Manajemen Ruang (SIMERU) yang diterapkan di Fakultas Teknologi Industri, Universitas Ahmad Dahlan Yogyakarta.

Tampubolon et al. (2013) melakukan penelitian tentang optimasi Quality Function Deployment (QFD) berbasis model kano. Berdasarkan analisis model optimisasi QFD didapat Call Setup Success Rate sebesar 90\%, Call Drop Rate sebesar 1\%, Paging Success Rate sebesar 91,7\%, Handover Success Rate sebesar 98,5\%, Mean Opinion Score sebesar 3,75, File Transfer Protocol (FTP), Throughtput sebesar 2,82 Mbps, Jumlah Kantor Pelayanan Pelanggan sebanyak 3 unit, CSSR Call Centre sebesar 10\%, Masa Berlaku Aktif Pulsa Prabayar selama tak terbatas, dan Besarnya
Kapasitas Memori Kartu SIM sebesar $64 \mathrm{~Kb}$. Magdalena et al. (2013) melakukan penelitian tentang peningkatan kualitas pelayanan dengan menggunakan metode Quality Function Deployment (QFD) di Rumah Sakit XYZ. Hasilnya terdapat 16 atribut variabel kebutuhan pelanggan. Berdasarkan hasil perhitungan gap diperoleh seluruh variabel pelayanan memiliki kesenjangan atau masih bernilai negatif. Variabel-variabel yang masih memiliki gap harus diperbaiki oleh pihak rumah sakit untuk meningkatkan kualitas pelayanan.

Variabel prosedur pelayanan yang tidak berbelit-belit menjadi prioritas perbaikan pertama pihak rumah sakit karena memiliki bobot yang paling besar. Karakteristik pelayanan diperoleh 11 karakteristik pelayanan yang digunakan dalam menilai kualitas pelayanan Rumah Sakit XYZ Medan, dimana karakteristik pelayanan yang menjadi prioritas pertama sebagai acuan perbaikan kualitas pihak manajemen rumah sakit adalah daya tanggap staf rumah sakit karena memiliki bobot tingkat kepentingan relatif tertinggi.

Mawarti et al., (2015) melakukan penelitian tentang analisis kualitas pelayanan puskesmas terhadap kepuasan Ibu hamil di Kota Pangkalpinang. Puskesmas perlu memberikan perhatian lebih pada area yang menimbulkan ketidakpuasan dan meningkatkan kinerjanya. Susila et al. (2014) melakukan penelitian tentang implementasi Quality Function Deployment (QFD) untuk meningkatkan layanan publik di RSUD Kabupaten Buleleng Bali. Atribut-atribut yang merupakan prioritas untuk diperhatikan dan dipenuhi oleh pengelola RSUD Kabupaten Buleleng berdasarkan pembobotan dari masing-masing atribut tersebut, yaitu: ruang rawat inap yang bersih, tempat tidur yang nyaman, kamar mandi yang bersih, tempat ibadah yang bersih, ruang rawat inap yang sejuk dan tenang, ruang parkir yang aman dan memadai, jaminan peralatan medis yang steril, pelayanan yang cepat dan akurat, tenaga medis yang profesional dan ruang parkir yang memadai dan aman. 
Tutuhatunewa (2010) melakukan penelitian tentang aplikasi QFD dalam pengembangan produk air minum kemasan, hasil dari penelitian ini adalah terdapat 7 atribut yang dianggap penting oleh konsumen dan dapat digunakan untuk mengukur kualitas produk air minum kemasan. Berdasarkan House of Quality menjamin bahwa seluruh peralatan produksi yang dipakai dalam keadaan yang benar-benar bersih, mengawasi proses produksi dengan ketat untuk memastikan kebersihannya, serta memastikan bahwa peralatan distribusi air dari lokasi bahan baku juga terjamin kebersihannya.

Suryaningrat dan Rendra (2014) meneliti tentang peningkatan kualitas produk tradisional prol tape dengan metode QFD hasil penelitiannya disimpulkan bahwa keinginan konsumen berdasarkan tingkat kepentingannya terfokus pada atribut produk prol tape adalah rasa, tekstur, warna, dan aroma. Produk prol tape yang menjadi obyek penelitiannya mencapai nilai tingkat kepuasan produk yang lebih tinggi dibandingkan dengan produk-produk pesaing karena produk tersebut mampu mencapai nilai target untuk semua respon teknis yang dimiliki. Rahman dan Supomo (2012) meneliti tentang analisa kepuasan pelanggan pada pekerjaan reparasi kapal dengan metode QFD, hasil penelitiannya menunjukkan bahwa nilai rata-rata selisih dari tiap atribut relatif sama, maka dinyatakan bahwa tingkat kepuasan pelanggan menunjukkan persepsi pelanggan belum mencapai pada harapan atau rata-rata dari nilai atribut belum mencerminkan tingkat kepuasan yang signifikan.

Pane et al. (2013) meneliti tentang upaya peningkatan kualitas jasa kesehatan menggunakan integrasi QFD dengan Analytical Hierarchy Process (AHP), hasil penelitiannya menunjukkan bahwa pengguna jasa menginginkan 15 variabel pelayanan yang segera mendapat prioritas perbaikan oleh pihak rumah sakit. Pengguna jasa juga menekankan pada atribut jadwal pelayanan tepat waktu, sedangkan pada hasil analisis AHP menunjukkan prioritas pada atribut tingkat pendidikan dan pengalaman kerja dibidangnya, artinya pihak rumah sakit memberdayakan tenaga medis dan non medis yang memiliki dasar pendidikan dan pengalaman kerja dibidang kesehatan.

Junaedi (2015) meneliti tentang perbaikan kualitas pelayanan jasa kepariwisataan dengan metode servqual dan QFD dan hasil dari QFD adalah Prioritas yang paling penting yang perlu yaitu tim kebersihan yang memadai, biaya pembongkaran, serta renovasi dan restorasi. Secara keseluruhan dapat diusulkan untuk meningkatkan layanan seperti: perbaikan sistem operasional, perbaikan dan penambahan fasilitas, penambahan sumber daya manusia dan pelatihan.

\section{METODE PENELITIAN Pendekatan Penelitian}

Jenis penelitian ini merupakan studi kasus, dengan menggunakan pendekatan kualitatif. Menurut Sugiyono (2010), metode penelitian kualitatif merupakan metode penelitian yang berlandaskan pada filsafat positivisme, digunakan untuk meneliti pada kondisi obyek yang alamiah, (sebagai lawannya adalah eksperimen) dimana peneliti adalah sebagai instrumen kunci, pengambilan sampel sumber data dilakukan secara purposive dan snowball. Teknik pengumpulan dengan trianggulasi, analisis data bersifat induktif/kualitatif, dan hasil penelitian kualitatif lebih menekan makna dari pada generalisasi. Studi kasus merupakan salah satu metode penelitian ilmu-ilmu sosial. Studi kasus adalah sebuah penyelidikan empiris yang menginvestigasi fenomena kontemporer dalam konteks kehidupan nyata, khususnya ketika batas antara fenomena dan konteks tidak begitu jelas (Yin, 2011).

\section{Populasi dan Sampel}

Populasi dalam penelitian ini adalah para pemohon SIM, rata-rata jumlah pemohon per hari 35 - 50 orang. Informan yang berpartisipasi diambil dengan batas maksimum yaitu ditentukan pada jumlah 120 
orang (Simamora, 2004). Agar data tidak terjadi bias maka jumlah sampel ditambah $20 \%$ sehingga menjadi 120 orang. Adapun karakteristik populasi yang dipilih atau ditetapkan oleh peneliti di dalam penelitian ini adalah pencari SIM yang berusia di atas 20 tahun, kriteria eksklusinya pencari SIM yang masih berstatus pelajar dan pencari SIM yang tidak bersedia diwawancarai. Teknik pengambilan sampel dilakukan dengan cara purposive dan snowball.

\section{Atribut Quality Function Deployment (QFD)}

Prosedur administrasi, materi tes teori, materi tes praktek, metode, kinerja petugas dan fasilitas. Masing-masing atribut memiliki indikator berdasarkan hasil pengamatan pada obyek penelitian.

\section{Teknis Analisis Data}

Menurut Cohen (1995), teknis analisis yang digunakan dalam penelitian ini adalah metode QFD, dengan langkah sebagai berikut: (1) Pada tahap awal analisis data dalam penelitian yaitu menentukan tujuan dan menentukan pelanggan; (2) Tahap Pengumpulan Suara Pelanggan (Voice of Customer); (3) Tahap Membangun Rumah Kualitas (House of Quality): (a) Menyusun Kebutuhan dan Keinginan Pelanggan' (b) Menyusun Matriks Perencanaan (Planning Matrix), (c) Kolom Kepentingan Pelanggan (Importance to Customer), (d) Kolom Kepuasan Pelanggan (Customer Satisfaction Performance), (e) Tujuan (Goal), (f) Rasio Perbaikan (Improvement Ratio), (f) Kolom Pembobotan (Raw Weight), (g) Menentukan Korelasi Teknis (Technical Correlation), (h) Menentukan Matriks Teknis

\section{ANALISIS DAN PEMBAHASAN}

Mengacu pada teori maupun penelitian terdahulu bahwa hasil akhir dari aplikasi QFD merupakan prioritas dari atribut produk atau jasa yang dibutuhkan dan dipentingkan oleh pelanggan, jenjang prioritas tersebut harus mendapat respon teknis dari pihak perusahaan dan menjadi fokus untuk proses dalam mendesain dan meningkatkan kualitas produk/jasa. Adapun hasil penelitian ini untuk melihat atribut yang dibutuhkan dan dipentingkan oleh pelanggan dilakukan tahapan sebagai berikut:

\section{Normalisasi Pembobotan (Normalized Raw Weight)}

Pada tahap ini setiap kelompok atribut akan dinilai bobot tertinggi dari nilai Raw Weight, apabila dalam kelompok atribut mendominasi predikat Raw Weight tertinggi maka pada akhirnya akan menjadi fokus perhatian bagi pihak manajemen sebagai dasar pertimbangan dari atribut yang dianggap memiliki tingkat kepentingan dan kepuasan. Kolom ini menyatakan normalisasi dari nilai Raw Weight, yaitu Raw Weight dibagi dengan total Raw Weight. Nilai dalam kolom ini mengandung informasi yang sama dengan kolom raw weight. Nilai ini digunakan untuk mempermudah perhitungan tahap selanjutnya dalam QFD. Hasil perhitungan normalized raw weight ini selengkapnya dapat dilihat pada tabel 2.

Penentuan nilai raw weight dalam setiap kelompok atribut dipilih pada setiap atribut yang memiliki nilai terbesar. Pada atribut prosedur administrasi terdapat 5 atribut, diketahui hasil nilai raw weight tertinggi adalah atribut pelayanan formulir pembuatan SIM sebesar 5,719, nilai ini akan menentukan besarnya tingkat kepentingan dan kepuasan para pencari SIM dalam menilai pelayanan yang diberikan oleh SATLANTAS Kabupaten Jombang akan terfokus pada atribut prosedur administrasi sedangkan ke empat atribut yang lain akan saling menunjang baik pada kelompok atribut prosedur administrasi maupun menunjang dalam kelompok atribut lain, hal ini akan terkait dengan penyusunan rumah kualitas. Pada kelompok atribut kedua yaitu waktu penyeleseian SIM dan biayaterdapat 2 atribut, pada atribut kejelasan biaya administrasi setiap jenis SIM yang tertera di papan pengumuman diketahui hasil nilai raw weight tertinggi sebesar 4,777, hal ini dimaksudkan bahwa 
Tabel 2

Matriks Perencanaan (Planning Matrix)

\begin{tabular}{|c|c|c|c|c|c|c|c|c|}
\hline \multicolumn{3}{|c|}{$\begin{array}{c}\text { Customer Need and Wants (Kebutuhan dan } \\
\text { Keinginan Pelanggan) }\end{array}$} & 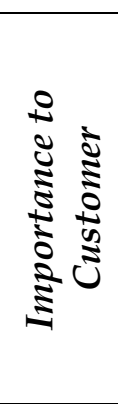 & 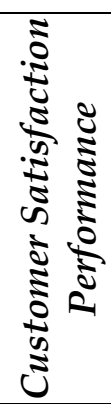 & $\bar{\Xi}$ & 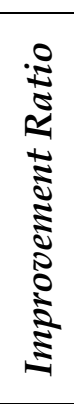 & 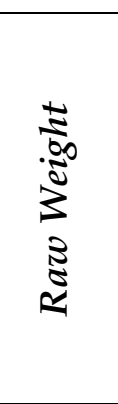 & 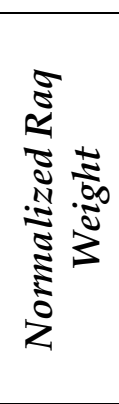 \\
\hline \multirow{5}{*}{ 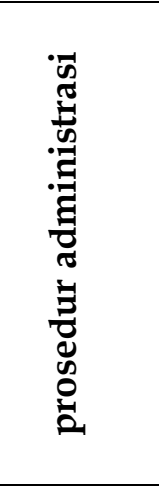 } & 1 & $\begin{array}{l}\text { Proses seleksi berdasarkan } \\
\text { kesesuaian KTP dengan } \\
\text { domisili }\end{array}$ & 4.027 & 3.067 & 3.067 & 1 & 4.027 & 0.0393 \\
\hline & 2 & Pelayanan tes kesehatan fisik & 4.593 & 3.293 & 4 & 1.2 & 5.579 & 0.0545 \\
\hline & 3 & $\begin{array}{l}\text { Pelayanan tes kesehatan } \\
\text { mental }\end{array}$ & 4.573 & 3.573 & 4 & 1.1 & 5.12 & 0.0500 \\
\hline & 4 & $\begin{array}{l}\text { Pelayanan formulir pembuatan } \\
\text { SIM }\end{array}$ & 4.48 & 3.133 & 4 & 1.3 & 5.719 & 0.0559 \\
\hline & 5 & $\begin{array}{l}\text { Kecepatan pelayanan } \\
\text { administrasi }\end{array}$ & 3.893 & 3.327 & 3.327 & 1 & 3.893 & 0.0380 \\
\hline \multirow{2}{*}{ 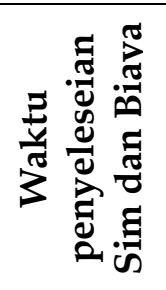 } & 6 & $\begin{array}{l}\text { Ketepatan waktu disetiap } \\
\text { tahapan proses (berkas, tes } \\
\text { tulis, ujian praktek dan photo) }\end{array}$ & 3.887 & 3.207 & 3.207 & 1 & 3.887 & 0.0380 \\
\hline & 7 & $\begin{array}{l}\text { Kejelasan biaya administrasi } \\
\text { Setiap jenis SIM yang tertera di } \\
\text { papan pengumuman }\end{array}$ & 3.813 & 3.193 & 4 & 1.3 & 4.777 & 0.0467 \\
\hline \multirow{6}{*}{ 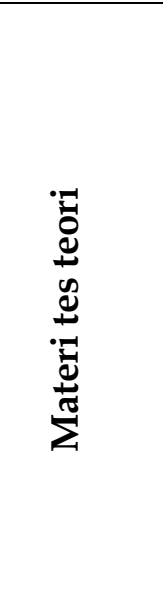 } & 8 & $\begin{array}{l}\text { Pengetahuan tentang rambu- } \\
\text { rambu lalu lintas }\end{array}$ & 4.58 & 3.613 & 4 & 1.1 & 5.071 & 0.0495 \\
\hline & 9 & $\begin{array}{l}\text { Pengetahuan tentang isyarat } \\
\text { petunjuk arah }\end{array}$ & 4.247 & 3.713 & 4 & 1.1 & 4.575 & 0.0447 \\
\hline & 10 & $\begin{array}{l}\text { Pengetahuan tentang syarat } \\
\text { perpindahan jalur }\end{array}$ & 4.7 & 3.46 & 4 & 1.2 & 5.434 & 0.0531 \\
\hline & 11 & $\begin{array}{l}\text { Pengetahuan tentang } \\
\text { penggunaan jalan }\end{array}$ & 4.38 & 2.973 & 2.973 & 1 & 4.38 & 0.0428 \\
\hline & 12 & $\begin{array}{l}\text { Pengetahuan tentang teknik } \\
\text { mengemudi }\end{array}$ & 3.867 & 3.187 & 4 & 1.3 & 4.853 & 0.0474 \\
\hline & 13 & $\begin{array}{l}\text { Pengetahuan tentang } \\
\text { perlengkapan pengendara }\end{array}$ & 3.007 & 3.3 & 4 & 1.2 & 4.857 & 0.0475 \\
\hline \multirow{4}{*}{ 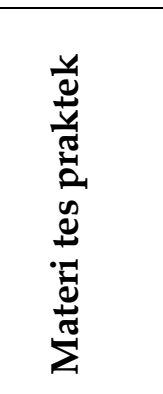 } & 14 & $\begin{array}{l}\text { Materi tes praktek dilengkapi } \\
\text { tanda-tanda lalu lintas }\end{array}$ & 4.727 & 3.467 & 4 & 1.2 & 5.454 & 0.0533 \\
\hline & 15 & $\begin{array}{l}\text { Ketersediaan kendaraan untuk } \\
\text { tes }\end{array}$ & 4.333 & 3.313 & 4 & 1.2 & 5.232 & 0.0511 \\
\hline & 16 & Variasi medan tes praktek & 4.387 & 3.487 & 4 & 1.1 & 5.003 & 0.0492 \\
\hline & 17 & $\begin{array}{l}\text { Ketersediaan papan panel } \\
\text { untuk menentukan secara } \\
\text { otomatis tingkat kelulusan }\end{array}$ & 4.287 & 3.227 & 4 & 1.2 & 5.314 & 0.0519 \\
\hline
\end{tabular}




\begin{tabular}{|c|c|c|c|c|c|c|c|c|}
\hline & & $\begin{array}{l}\text { dalam setiap tahapan ujian } \\
\text { praktek }\end{array}$ & & & & & & \\
\hline \multirow{4}{*}{$\frac{0}{8}$} & 18 & $\begin{array}{l}\text { Pengarahan petugas kepada } \\
\text { peserta sebelum tes dimulai }\end{array}$ & 3.847 & 3.2 & 3.2 & 1 & 3.847 & 0.0376 \\
\hline & 19 & $\begin{array}{l}\text { Pengarahan dan pemberian } \\
\text { Contoh sebelum ujian praktek } \\
\text { dimulai }\end{array}$ & 3.533 & 3.027 & 3.027 & 1 & 3.533 & 0.0345 \\
\hline & 20 & $\begin{array}{l}\text { Metode mengendarai dalam } \\
\text { berbagai bentuk jalan (lurus, } \\
\text { zig zag memutar) }\end{array}$ & 3.213 & 2.833 & 3.833 & 1 & 3.513 & 0.0343 \\
\hline & 21 & $\begin{array}{l}\text { Pengarahan tentang teknik } \\
\text { konsentrasi dalam berkendara }\end{array}$ & 3.653 & 2.987 & 2.987 & 1 & 3.653 & 0.0357 \\
\hline \multirow{6}{*}{ 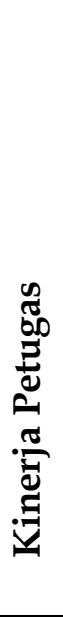 } & 22 & $\begin{array}{l}\text { Kecekatan petugas dalam } \\
\text { menangani proses tes praktek }\end{array}$ & 4.26 & 2.78 & 3 & 1.1 & 4.597 & 0.0449 \\
\hline & 23 & $\begin{array}{l}\text { Kecekatan petugas dalam } \\
\text { menangani proses tes tulis. }\end{array}$ & 3.801 & 2,77 & 3,5 & 1.1 & 3.511 & 0.0447 \\
\hline & 24 & $\begin{array}{l}\text { Memiliki kemampuan dalam } \\
\text { memberikan pengetahuan } \\
\text { berlalu lintas }\end{array}$ & 3.800 & 2,75 & 4 & 1.2 & 3.510 & 0.0443 \\
\hline & 25 & $\begin{array}{l}\text { Kecekatan petugas menangani } \\
\text { proses administrasi }\end{array}$ & 3.229 & 2.73 & 4 & 1.2 & 3.509 & 0.0443 \\
\hline & 26 & $\begin{array}{l}\text { Kecekatan petugas menangani } \\
\text { proses tes kesehatan }\end{array}$ & 3.227 & 2.71 & 4 & 1.2 & 3.507 & 0.0442 \\
\hline & 27 & $\begin{array}{l}\text { Petugas memberi kesempatan } \\
\text { bertanya }\end{array}$ & 3.221 & 2.69 & 4 & 1.2 & 3.505 & 0.0439 \\
\hline \multirow{4}{*}{ 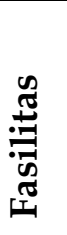 } & 28 & $\begin{array}{l}\text { Ketersediaan kendaraan untuk } \\
\text { praktek }\end{array}$ & 3.219 & 2.67 & 3.5 & 1.1 & 3.504 & 0.0437 \\
\hline & 29 & Ruang ber-AC & 3.217 & 2.66 & 4 & 1.2 & 3.502 & 0.0435 \\
\hline & 30 & Ketersediaan ruang tunggu & 3.215 & 2.65 & 4 & 1.2 & 3.500 & 0.0434 \\
\hline & 31 & Ketersediaan area parkir & 3.213 & 2.63 & 4 & 1.2 & 3.498 & 0.0433 \\
\hline
\end{tabular}

Sumber : data Primer yang diolah tahun 2016

kejelasan biaya administrasi setiap jenis SIM secara transparan dipandang sangat penting dan memuaskan bagi masyarakat pencari SIM atau dengan kata lain atribut tersebut menjadi fokus perhatian bagi pihak manajemen SATLANTAS Kabupaten Jombang.

Pada kelompok atribut materi tes teori terdapat 6 atribut, pada atribut pengetahuan tentang syarat perpindahan jalur hasil nilai raw weight tertinggi sebesar 5.434 . Hal ini menunjukkan bahwa atribut pengetahuan tentang syarat perpindahan jalur menjadi penting bagi pencari SIM.

Pada kelompok atribut materi tes praktek terdapat 4 atribut, pada atribut materi tes praktek dilengkapi tanda-tanda lalu lintas diketahui hasil nilai raw weight tertinggi sebesar 5,454. Pada kelompok atribut ini menunjukkan kesatuan kompetensi yang harus dimiliki oleh para pencari SIM dalam melaksanakan ujian praktek dimana pihak SATLANTAS telah melengkapi dengan beberapa fasilitas yang dibutuhkan. Pada kelompok atribut metode terdapat 4 atribut, pada atribut pengarahan petugas kepada peserta sebelum tes dimulai diperoleh hasil nilai raw weight tertinggi sebesar 3,847, hal ini dianggap paling penting diantara 3 atribut lainnya oleh masyarakat pencari SIM selain itu juga para pencari SIM juga menilai tingkat kepuasan yang diterima sangat bagus karena pada kenyataannya para petugas memberikan pengarahan yang sejelasjelasnya sebelum tes dimulai. 
Pada kelompok atribut kinerja petugas terdapat 6 atribut, pada atribut kecekatan petugas dalam menangani proses tes praktek diketahui hasil nilai raw weight tertinggi sebesar 4,597. Atribut ini sangat terkait dengan kelompok atribut materi tes praktek jadi ada keeratan hubungan dalam 2 jenis atribut tersebut.

Pada kelompok atribut fasilitas terdapat 4 atribut, pada atribut kesediaan kendaraan untuk praktek diketahui hasil nilai raw weight tertinggi sebesar 3,504, jika diamati atribut ini memang sangat dipertimbangkan oleh para pencari SIM meskipun hampir semua para pencari SIM membawa dan memakai kendaraan sendiri untuk tes praktek, namun sebenarnya para pencari SIM menginginkan kendaraan yang standar khusus sebagai sarana tes.

\section{Analisa Kebutuhan dan Keinginan Pelanggan}

Kebutuhan dan keinginan pelanggan dianalisis melalui matriks perencanaan yang terletak di "dinding" sebelah kanan dari rumah kualitas. Matriks perencanaan tersebut menggambarkan rata-rata tingkat kepentingan dan tingkat kepuasan dari kebutuhan dan keinginan atau atribut pelanggan, tujuan serta Improvement Ratio. Gambaran keseluruhan dari kebutuhan dan keinginan yang dipentingkan oleh pelanggan dapat dilihat dari nilai-nilai pada kolom pembobotan.

Dari nilai-nilai tersebut dapat dibuat urutan atau peringkat masing-masing kebutuhan dan keinginan yang dipentingkan oleh pelanggan mulai dari yang tertinggi sampai dengan urutan yang terendah seperti yang ditunjukkan pada Tabel 3. Berdasarkan tabel 3 dapat dijelaskan mengenai peringkat raw weight pada 9 peringkat dengan analisa sebagai berikut:

Pelayanan formulir pembuatan SIM menjadi atribut peringkat pertama yang dipentingkan pelanggan. Hal ini dikarenakan adanya opini dalam diri pencari SIM tentang pentingnya atribut tersebut untuk mendapat respon yang positif dari pihak pengelola, adapun respon yang diberikan adalah dengan cara memberikan berbagai kemudahan dalam pelayanan formulir mengingat hal ini dapat menumbuhkan minat para pencari SIM sekaligus menumbuhkan kesadaran terhadap kedisiplinan dalam berkendara, maka dengan pelayanan yang dirasakan mudah maka akan memperlancar berbagai proses. Berdasarkan nilai improvement ratio sebesar 1,3; maka diperlukan usaha yang cukup besar untuk memperbaiki atribut ini agar kepuasan pelanggan dapat makin meningkat menjadi lebih puas. Atribut ini sebaiknya lebih diperhatikan lagi oleh pihak pengelola, karena hal ini berkaitan erat dengan ketertarikan masyarakat untuk memiliki SIM.

Peringkat kedua dari atribut yang dipentingkan pelanggan adalah pelayanan tes kesehatan fisik. Pihak pengelola SATLANTAS Kabupaten Jombang telah berusaha memberi fasilitas tes kesehatan dilingkungan SATLANTAS agar proses dapat dilakukan lebih cepat, efektif dan efisien. Improvement ratio sebesar 1,2; artinya improvement yang dilakukan agar atribut ini dapat meningkatkan kepuasan pelanggan cukup besar. Sebaiknya atribut ini diperhatikan oleh pihak pengelola, karena masyarakat pada umumnya tidak ingin menghadapi masalah yang dianggap ribet. Salah satu cara yang dapat digunakan untuk meningkatkan adalah menyatukan berbagai proses pelayanan agar dapat ditempuh dengan aman, mudah dan cepat dalam satu lokasi.

Peringkat ketiga dari atribut yang dipentingkan pencari SIM adalah materi tes praktek dilengkapi tanda-tanda lalu lintas. Pihak pengelola SATLANTAS Kabupaten Jombang mempunyai kemampuan untuk selalu meng-update materi tes praktek dilengkapi tanda-tanda lalu lintas bahkan kasus-kasus empiris. Improvement ratio-nya 1,2 mengindikasikan bahwa diperlukan usaha yang cukup besar untuk memperbaiki atribut ini agar kepuasan pelanggan juga semakin meningkat. Dengan demikian pihak pengelola SATLANTAS Kabupaten Jom- 
Tabel 3

Peringkat Atribut yang Dipentingkan oleh Pemohon SIM tahun 2016

\begin{tabular}{|c|c|c|}
\hline Peringkat & Raw Weight & ATRIBUT PELANGGAN \\
\hline 1 & 5.719 & Pelayanan formulir pembuatan SIM \\
\hline 2 & 5.579 & Pelayanan tes kesehatan fisik \\
\hline 3 & 5.454 & Materi tes praktek dilengkapi tanda-tanda lalu lintas \\
\hline 4 & 5.434 & Pengetahuan tentang syarat perpindahan jalur \\
\hline 5 & 5.314 & $\begin{array}{l}\text { Ketersediaan papan panel untuk menentukan secara } \\
\text { otomatis tingkat kelulusan dalam setiap tahapan ujian. }\end{array}$ \\
\hline 6 & 5.232 & Ketersediaan kendaraan untuk tes \\
\hline 7 & 5.12 & Pelayanan tes kesehatan mental \\
\hline 8 & 5.071 & Pengetahuan tentang rambu-rambu lalu lintas \\
\hline 9 & 5.033 & Variasi medan tes praktek \\
\hline 10 & 4.857 & Pengetahuan tentang perlengkapan pengendara \\
\hline 11 & 4.853 & Pengetahuan tentang teknik mengemudi \\
\hline 12 & 4.777 & $\begin{array}{l}\text { Kejelasan biaya administrasi setiap jenis SIM yang tertera di } \\
\text { papan pengumuman }\end{array}$ \\
\hline 13 & 4.597 & Kecekatan petugas dalam menangani proses tes praktek \\
\hline 14 & 4.575 & Pengetahuan tentang isyarat petunjuk arah \\
\hline 15 & 4.38 & Pengetahuan tentang penggunaan jalan \\
\hline 16 & 4.027 & Proses seleksi berdasarkan kesesuaian KTP dengan domisili \\
\hline 17 & 3.893 & Kecepatan pelayanan administrasi \\
\hline 18 & 3.887 & $\begin{array}{l}\text { Ketepatan waktu disetiap tahapan proses (berkas,tes tulis, } \\
\text { ujian praktek dan photo) }\end{array}$ \\
\hline 19 & 3.847 & Pengarahan petugas kepada peserta sebelum tes dimulai \\
\hline 20 & 3.653 & Pengarahan tentang teknik konsentrasi dalam berkendara \\
\hline 21 & 3.533 & $\begin{array}{l}\text { Pengarahan dan pemberian contoh sebelum ujian praktek } \\
\text { dimulai }\end{array}$ \\
\hline 22 & 3.513 & $\begin{array}{l}\text { Metode mengendarai dalam berbagai bentuk jalan (lurus, } \\
\text { zig zag memutar) }\end{array}$ \\
\hline 23 & 3.511 & Kecekatan petugas dalam menangani proses tes tulis \\
\hline 24 & 3.510 & $\begin{array}{l}\text { Memiliki kemampuandalam memberikan pengetahuan } \\
\text { berlalu lintas }\end{array}$ \\
\hline 25 & 3.509 & Kecekatan petugas menangani proses administrasi \\
\hline 26 & 3.507 & Kecekatan petugas menangani proses tes kesehatan \\
\hline 27 & 3.505 & Petugas memberi kesempatan bertanya \\
\hline 28 & 3.504 & Ketersediaan kendaraan untuk praktek \\
\hline 29 & 3.503 & Ruang ber-AC \\
\hline 30 & 3.502 & Ketersediaan ruang tunggu \\
\hline 31 & 3.500 & Ketersediaan area parkir \\
\hline
\end{tabular}

bang harus selalu mengikuti kemajuankemajuan teknologi dan perkembangan sesuai kondisi saat ini. Peringkat keempat dari atribut yang dipentingkan oleh pelanggan adalah pengetahuan tentang syarat perpindahan jalur. Atribut ini perlu dipahami karena merupakan unsur penambahan pengetahuan sekaligus pendidikan bagi masyarakat atau pencari SIM karena peluang untuk melalui medan tempuh yang bervariasi di luar daerah Jombang sangat besar.

Ketersediaan papan panel untuk menentukan secara otomatis tingkat kelulusan 
dalam setiap tahapan ujian praktek peringkat kelima dari atribut yang dipentingkan pencari SIM adalah ketersediaan papan panel untuk menentukan secara otomatis tingkat kelulusan dalam setiap tahapan ujian praktek. Bagi masyarakat pencari SIM proses kelulusan memang sangat penting dan kondisi saat ini dimana setiap institusi dituntut untuk transparan dalam memperlihatkan tingkat kelulusan dari setiap tahapan proses. Improvement ratio-nya 1,2; yang artinya alat tersebut merupakan bukti otentik terhadap tingkat kelulusan dari setiap tahapan tes, jadi tidak akan terjadi manipulasi pada nilai hasil tes. Hal ini merupakan kinerja yang bagus dari pihak SATLANTAS sebagai institusi negara.

Peringkat keenam dari atribut yang dipentingkan pencari SIM adalah ketersediaan kendaraan untuk tes. Pihak pengelola SATLANTAS Kabupaten Jombang dalam memberikan fasilitas layanan dengan menyediakan kendaraan untuk tes dengan tujuan untuk membantu para peserta tes dalam mengurangi kesulitan pada saat tes berlangsung dan fasilitas tersebut benarbanar memadai. Nilai improvement ratio sebesar 1,2 menunjukkan perlunya upaya yang cukup besar memperbaiki atribut ini agar kepuasan pelanggan juga semakin meningkat. Dengan demikian pihak pengelola SATLANTAS Kabupaten Jombang harus memperhatikan kondisi fisik kendaraan yang digunakan untuk memfasilitas kegiatan ujian praktek SIM.

Peringkat ketujuh dari atribut yang dipentingkan pencari SIM adalah pelayanan tes kesehatan mental. Pihak pengelola SATLANTAS Kabupaten Jombang mempunyai trik-trik khusus untuk menguji mental peserta karena hal ini sangat terkait dengan kesabaran sebagai pengguna jalan sehubungan dengan banyaknya kasus yang terjadi saat berkendara. Improvement rationya 1,1 menunjukkan bahwa diperlukan usaha yang cukup besar untuk menumbuhkan motivasi mengenai peningkatan kedisiplinan dalam berkendara. Dengan demikian pihak pengelola SATLANTAS Kabu- paten Jombang harus memperketat displin lalu lintas di seluruh elemen masyarakat untuk mengurangi tingkat kecelakaan yang terjadi dari waktu ke waktu.

Peringkat kedelapan dari atribut yang dipentingkan pencari SIM adalah pengetahuan tentang rambu-rambu lalu lintas. Pihak pengelola SATLANTAS Kabupaten Jombang mempunyai kewajiban untuk menginformasikan rambu-rambu lalu lintas kepada masyarakat secara spesifik maupun umum agar semua elemen masyarakat memahami dan menumbuhkan motivasi pada mereka untuk berbagi informasi mengingat hal tersebut bermuara untuk kepentingan umum. Nilai improvement ratio sebesar 1,2 mengindikasikan bahwa diperlukan usaha yang cukup besar untuk memperbaiki atribut ini agar kepuasan pelanggan juga semakin meningkat.

Peringkat kesembilan dari atribut yang dipentingkan pencari SIM adalah variasi medan tes praktek. Pihak pengelola SATLANTAS Kabupaten Jombang mempunyai variasi medan tes yang bersifat umum atau banyak dijumpai oleh peserta sehingga pada saat mereka dihadapkan pada berbagai bentuk medan akan dapat dilalui dengan mudah. Improvement ratio sebesar 1,3 menunjukkan bahwa diperlukan usaha yang cukup besar untuk memperbaiki atribut ini agar kepuasan pelanggan juga semakin meningkat, maka pihak pengelola SATLANTAS Kabupaten Jombang harus menampilkan medan ujian praktek yang pada dasarnya mampu menumbuhkan strategi khusus untuk dapat melalui dengan mudah dan menjamin keamanan pengendara. Hal ini penting karena memungkinkan bagi pencari SIM yang lulus akan dihadapkan pada medan yang jauh lebih sulit.

\section{Analisa Matriks Hubungan (Relation Matrix)}

Hubungan antara kebutuhan dan keinginan pelanggan dengan respon teknis dianalisis melalui matriks hubungan yang terletak di "dinding tengah" dari rumah kualitas. Matriks hubungan ini meng- 
gambarkan pengaruh respon teknis yang disediakan oleh pengelola terhadap pemenuhan kebutuhan dan keinginan masyarakat pencari SIM. Pengaruh ini dilambangkan dengan angka 0, 1, 3 dan 9 dengan melihat "dinding tengah" dapat diinterpretasikan pengaruh dari respon teknis terhadap kepuasan pelanggan yaitu:

Nilai 0 pada matrik hubungan menunjukkan respon teknis tidak berpengaruh terhadap performansi kepuasan atas kebutuhan dan keinginan pelangggan. Artinya bila terjadi perubahan respon teknis, baik kecil maupun besar, maka tidak ada perubahan dalam kepuasan pelanggan. Hal ini telah terjadi pada atribut: kecekatan petugas menangani proses administrasi, kecekatan petugas menangani proses tes kesehatan, petugas memberi kesempatan bertanya, ketersediaan kendaraan untuk praktek, ruang ber-AC, ketersediaan ruang tunggu dan ketersediaan area parkir. Atribut-atribut tersebut menduduki peringkat terbawah, secara empiris dapat dikaji bahwa atribut tersebut tidak merubah keputusan pelanggan mengingat kebijakan diambil pihak pengelola dianggap sesuai oleh masyarakat pencari SIM.

Nilai 1 pada matrik hubungan menunjukkan respon teknis yang diberikan oleh pihak manajemen kecil pengaruhnya terhadap performansi kepuasan atas kebutuhan dan keinginan pelanggan. Artinya untuk perubahan respon teknis yang relatif besar, hanya sedikit terjadi perubahan dalam kepuasan pelanggan. Hal ini telah terjadi pada atribut: pengarahan petugas kepada peserta sebelum tes dimulai, pengarahan tentang teknik konsentrasi dalam berkendara, pengarahan dan pemberian contoh sebelum ujian praktek dimulai, metode mengendarai dalam berbagai bentuk jalan (lurus, zig zag memutar, kecekatan petugas dalam menangani proses tes tulis, dan atribut memiliki kemampuan dalam memberikan pengetahuan berlalu lintas. Berdasarkan analisis secara empiris yang diuraikan sebelumnya dapat diamati bahwa perubahan respon teknis yang relatif besar pada atribut tersebut tidak berdampak besar terhadap perubahan dalam kepuasan pelanggan artinya meskipun petugas memberikan pengetahuan secara maksimal namun para pencari SIM memiliki banyak keterbatasan baik kemampuan, waktu latihan maupun pengetahuan.

Nilai 3 pada matrik hubungan menunjukkan bahwa respon teknis pengaruhnya sedang (moderate) terhadap performansi kepuasan pelanggan atas kebutuhan dan keinginannya. Artinya untuk perubahan respon teknis yang relatif besar, terjadi perubahan tetapi tidak terlalu besar dalam kepuasan pelanggan. Hal ini telah terjadi pada atribut: pengetahuan tentang perlengkapan pengendara, pengetahuan tentang teknik mengemudi, kejelasan biaya administrasi setiap jenis SIM yang tertera di papan pengumuman, kecekatan petugas dalam menangani proses tes praktek, pengetahuan tentang isyarat petunjuk arah, pengetahuan tentang penggunaan jalan, pengetahuan tentang perlengkapan pengendara, kecepatan pelayanan administrasi dan ketepatan waktu disetiap tahapan proses (berkas, tes tulis, ujian praktek dan foto). Jika dikaji secara empiris atribut tersebut terdapat perubahan respon teknis yang relatif besar tetapi tidak bardampak signifikan terhadap kepuasan pelanggan, hal ini disebabkan sebagian besar para pencari SIM memang telah memahami atribut tersebut melalui pengetahuan yang diperoleh secara tidak langsung di lapangan.

Nilai 9 pada matrik hubungan menunjukkan bahwa respon teknis sangat kuat terhadap kepuasan pelanggan. Artinya sedikit saja terjadi perubahan dalam respon teknis, maka terjadi perubahan besar dalam kepuasan pelanggan. Jika dikaji secara empiris respon teknis sangat kuat pada atribut tersebut terhadap performansi kepuasan pelanggan atas kebutuhan dan keinginan pencari SIM hal ini karena pihak masyarakat pencari SIM menginginkan transparansi dalam setiap tahapan proses mendapatkan SIM. 


\section{Analisa Kolerasi Teknis}

Berdasarkan gambar yang menunjukkan korelasi antar respon teknis maka dapat diinterpretasikan sebagai berikut: Korelasi positif yang sangat kuat $(++)$ terjadi antara respon teknis, yaitu: pada atribut pelayanan formulir pembuatan SIM, pelayanan tes kesehatan fisik, materi tes praktek dilengkapi tanda-tanda lalu lintas, pengetahuan tentang syarat perpindahan jalur, ketersediaan papan panel untuk menentukan secara otomatis tingkat kelulusan dalam setiap tahapan ujian praktek, ketersediaan kendaraan untuk tes dan pelayanan tes kesehatan mental, pengetahuan tentang rambu-rambu lalu lintas dan variasi medan tes praktek. Hal ini terjadi karena adanya transpransi pada prosedur dalam tahapan tes maupun bukti konkrit dari setiap kelulusan peserta tes.

Korelasi positif yang sedang $(+)$ terjadi antara respon teknis, yaitu pada atribut pengetahuan tentang perlengkapan pengendara, pengetahuan tentang teknik mengemudi, kejelasan biaya administrasi setiap jenis SIM yang tertera di papan pengumuman, kecekatan petugas dalam menangani proses tes praktek, pengetahuan tentang isyarat petunjuk arah, pengetahuan tentang penggunaan jalan, pengetahuan tentang perlengkapan pengendara, kecepatan pelayanan administrasi dan ketepatan waktu disetiap tahapan proses (berkas, tes tulis, ujian praktek dan foto). Hal ini dapat dikaji secara empiris bahwa atribut tersebut karena adanya kesesuaian semua informasi yang terkait dengan materi dan prosedur tes yang disampaikan oleh petugas dan dirasakan penting oleh para pencari SIM.

Korelasi negatif yang sangat kuat (- -) terjadi antara respon teknis yaitu pada atribut kecekatan petugas menangani proses administrasi, kecekatan petugas menangani proses tes kesehatan, petugas memberi kesempatan bertanya, kesediaan kendaraan untuk praktek, ruang ber-AC, ketersediaan ruang tunggu dan ketersediaan area parkir hal ini dikarenakan persepsi masyarakat terhadap atribut-atribut tersebut memang merupakan standar pelayanan jasa secara umum. Korelasi negatif yang sedang (-) terjadi antara respon teknis, yaitu pada atribut pengarahan petugas kepada peserta sebelum tes dimulai, pengarahan tentang teknik konsentrasi dalam berkendara, pengarahan dan pemberian contoh sebelum ujian praktek dimulai, metode mengendarai dalam berbagai bentuk jalan (lurus, zig zag memutar, kecekatan petugas dalam menangani proses tes tulis, dan atribut memiliki kemampuan dalam memberikan pengetahuan berlalu lintas. Atribut tersebut dinilai tidak seberapa penting karena para pencari SIM memiliki pandangan terhadap atribut ter- sebut sebagai pengetahuan umum yang sebenarnya sudah diketahui sebelumnya.

\section{Analisa Prioritas}

Kolom prioritas terletak di bagian "dasar" dari rumah kualitas. Kolom prioritas ini menunjukkan gambaran kontribusi respon teknis, semakin besar pengaruh respon teknis tersebut terhadap performansi kepuasan pelanggan, maka semakin penting respon teknis ini untuk dilaksanakan sebaikbaiknya. Dari nilai yang tersebut dapat dibuat urutan atau peringkat respon teknis mulai dari yang tertinggi sampai yang terendah.

\section{SIMPULAN DAN SARAN Simpulan}

Terdapat sembilan atribut yang dianggap penting dan mampu membuat masyarakat pencari SIM puas sehingga atribut tersebut perlu diperhatikan pihak pengelola SATLANTAS Kabupaten Jombang. Atribut tersebut adalah (a) Pelayanan formulir pembuatan SIM menjadi atribut peringkat pertama yang dipentingkan pelanggan. Pihak pengelola telah memberikan kemudahan dalam pelayanan formulir,hal ini berdampak pada minat pencari SIM dan kedisiplinan dalam berkendara, (b) Peringkat kedua adalah pelayanan tes kesehatan fisik, (c) Peringkat ketiga adalah materi tes praktek dilengkapi tanda-tanda lalu lintas, (d) Peringkat keempat pengetahuan tentang syarat perpindahan jalur, (e) Peringkat ke- 
lima ketersediaan papan panel untuk menentukan secara otomatis tingkat kelulusan dalam setiap tahapan ujian praktek, (f) Peringkat keenam adalah ketersediaan kendaraan untuk tes, (g) Peringkat ketujuh adalah pelayanan tes kesehatan mental, (h) Peringkat delapan adalah pengetahuan tentang rambu-rambu lalu lintas, (i) Peringkat kesembilan adalah variasi medan tes praktek. Berdasarkan analisa korelasi antar respon teknis diketahui bahwa terdapat (a) Korelasi positif yang sangat kuat $(++)$. Hal ini terjadi karena adanya transparansi pada prosedur dalam tahapan tes maupun bukti konkrit dari setiap kelulusan peserta tes, (b) Korelasi positif yang sedang $(+)$. Hal ini karena adanya kesesuaian semua informasi yang terkait dengan materi dan prosedur tes yang disampaikan oleh petugas dan dirasakan penting oleh para pencari SIM, (c) Korelasi negatif yang sangat kuat (--). Hal ini dikarenakan atribut tersebut memang merupakan standar pelayanan jasa secara umum, (d) Korelasi negatif yang sedang (-). Atribut tersebut dinilai tidak seberapa penting karena para pencari SIM memiliki pandangan terhadap atribut tersebut sebagai pengetahuan umum yang sebenarnya sudah diketahui sebelumnya.

Analisa prioritas, kolom prioritas terletak di bagian "dasar" dari rumah kualitas. Kolom prioritas ini menunjukkan gambaran kontribusi respon teknis, semakin besar pengaruh respon teknis tersebut terhadap performansi kepuasan pelanggan, maka semakin penting respon teknis ini untuk dilaksanakan sebaik-baiknya.

\section{Saran}

Saran yang dapat dikemukakan dari hasil penelitian ini adalah: (1). Berdasarkan atribut yang terdapat pada peringkat 1 sampai 9 telah dinilai pencari SIM sebagai atribut yang dianggap penting dan sudah memuaskan maka diharapkan pihak SATLANTAS Kabupaten Jombang melakukan pembenahan terhadap atribut yang berada dibawa kesembilan atribut tersebut karena kondisi tersebut mampu menciptakan image yang baik dimata masyarakat sekaligus sebagai bahan pertimbangan dalam menentukan keputusan untuk mencari SIM pada SATLANTAS Kabupaten Jombang; (2) Respon teknis sebenarnya adalah harapan terbesar dari masyarakat pencari SIM karna pada dasarnya mereka menuntut adanya pembenahan terhadap kekurangan yang ada di SATLANTAS Kabupaten Jombang, untuk itu phak pengelolah harus merespon baik terhadap apa yang dikeluhkan oleh masyarakat karena hal tersebut demi kebaikan institusi SATLANTAS Kabupaten Jombang; (3) Atribut-atribut yang memiliki korelasi teknis positif maupun negatif yang sangat kuat sebaknya dipertahankan agar prestige institusi SATLANTAS Kabupaten Jombang tetap baik dimata masyarakat karena hal tersebut merupakan salah satu sarana motivasi yang handal bagi masyarakat untuk terpacu memiliki SIM sebagai kesadaran masyarakat yang bersifat wajib untuk memiliki SIM; (4) Berdasarkan analisa prioritas maka seharusnya pihak pengelolah SATLANTAS Kabupaten Jombang memberikan respon yang baik terhadap apa yang dikeluhkan masyarakat, jika memang pihak pengelola belum dapat melaksanakan respon teknis maka hendaknya tetap memberikan tanggapan yang cukup baik untuk disampaikan kepada masyarakat sehingga mereka tidak kecewa.

\section{Keterbatasan Penelitian}

Penelitian ini memiliki keterbatasan yang perlu diperhatikan, pertama adalah pemilihan partisipan yang terlibat relatif kecil yaitu 120 yang terbagi secara proporsional dalam strata sampel sehingga jika digeneralisasi terhadap seluruh komunitas masyarakat pencari SIM di Jombang dianggap kurang mewakili. Kedua, pengalaman para pencari SIM yang digunakan sebagai sampel dalam penelitian ini bersifat variatif. Ketiga, hasil penelitian tidak dapat mewakili gambaran pola QFD untuk pelanggan pada usaha lain baik milik pemerintah maupun swasta oleh karena itu diperlukan research setting yang berbeda 
untuk melihat tingkat kepuasan dan tingkat kepentingan yang diprioritaskan pelanggan dalam mengkonsumsi layanan jasa.

\section{DAFTAR PUSTAKA}

Arief, M. 2011. Kualitas Pelayanan Publik di Bandara Internasional Sultan Hasanuddin Makasar (Studi Kasus Pelayanan Jasa Penumpang). Jurnal ACADEMICA Fisip Untad 3(2): 729-740.

Benjamin, C. O., M. Watkins, dan M. Murtaza. 1999. A QFD Framework for Curriculum Planning. ASEE Proceedings.

Crie, D. 2003. Consumers' Complaint Behaviour. Taxonomy, Typology and Determinants: Towards a Unified Ontology. Journal of Database Marketing \& Customer Strategy Management 11(1): 60-79.

Chevri, E. P. dan Iskandar. 2015. Analisis Kepuasan Pelanggan terhadap Kualitas Layanan dengan Metode Quality Function Deployment (QFD) pada PT ASCO PRIMA MOBILINDO.Jurnal Teknik mesin 1(1): 93-99.

Cohen, L. 1995. Quality Function Deployment: How to Make QFD Work for You. Engineering Process Improvement Series. Wesley Publishing Company. USA.

Destyasa, E. W., N. W. Setyanto, dan C. F. M. Tantrika. 2013.Analisis Kualitas Jasa Listrik Prabayar dengan Mengintegrasikan Metode Service Quality (SERVQUAL) dan Quality Function Deployment (QFD) (Studi Kasus PT. Perusahaan Listrik Negara (Persero),Tbk.). Jurnal Rekayasa dan Manajemen Sistem Industri 1(2): 218-228.

Devani, V. dan D. D. Kartikasari. 2012. Usulan Perbaikan Kualitas Pelayanan Administrasi Mahasiswa Menggunakan Metode Quality Function Deployment (QFD). Jurnal Ilmiah Teknik Industri 11(2): 185-197.

Dharmawan, A. dan F. Wurjaningrum. 2014. Rancangan Perbaikan Kualitas Pelayanan Jasa dengan Metode Servqual, Importance Performance Analysis, dan Quality Function Deployment pada
Plasa Telkom Cabang Dinoyo Surabaya. Jurnal Manajemen Teori dan Terapan 7(3): 207-224.

Djunaidi, M., A. K. Alghofari, dan D. A. Rahayu. 2006. Penilaian Kualitas Jasa Pelayanan Lembaga Bimbingan Belajar PRIMAGAMA Berdasarkan Preferensi Konsumen. Jurnal Ilmiah Teknik Industri 5(1): 25-32.

Erni, N., I. K. Sriwana, dan D. Karisa. 2013. Peningkatan Kualitas Jasa Pelayanan dengan Metode Servqual dan Quality Function Deployment. Jurnal Ilmiah Teknik Industri 1(1): 59-66.

Fuad, A., N. Azis, dan M. Yunus. 2012. Pengaruh Lingkungan Pemasaran dan Penerapan Strategi Pemasaran Terpadu terhadap Kepuasan Pelanggan serta Implikasinya terhadap Keunggulan Bersaing Usaha Jasa Rental Mobil di Kota Banda Aceh. Jurnal Ilmu Manajemen Pascasarjana Universitas Syiah Kuala 1(1): 57-75.

Hwarng, H. B. danC. Teo. 2001. Translating Customers' Voices into Operations Requirements - A QFD Application in Higher Education. International Journal of Quality and Reliability Management18(2): 195-226.

Irawan, A. dan M. N. Iqsan. 2012, Analisa Kualitas Pelayanan Rumah Makan Mahkota dengan Penerapan Metode Quality Function Deployment (QFD). Jurnal Ilmiah dan Teknologi, Fakultas Teknik dan Fakultas MIPA Universitas Pamulang 8(20): 34-55.

Indriani, S. dan S. A. Sari. 2011. Penerapan Metode Quality Function Deployment (QFD) sebagai Upaya untuk Peningkatan Kualitas Pelayanan. Jurnal Teknologi Technoscientia 4(1): 111-121.

Junaedi, D. 2015. Perbaikan Kualitas Pelayanan Jasa Kepariwisataan dengan Metode Servqual dan QFD (Studi Kasus di Keraton Kasepuhan Kota Cirebon). Jurnal OE 7(1): 33-49.

Kärnä, S. 2004. Analysing Customer Satisfaction and Quality in Construction: The Case of Public and Private Customers. 
Nordic Journal of Surveying and Real Estate Research 2: 67-80.

Kotler, P. dan K. L. Keller. 2012. Marketing Management. Pearson Prentice Hall. New Jersey.

Lijan, S. 2014. Reformasi Pelayanan Publik. PT. Bumi Aksara.Jakarta.

Lovelock, C. dan Gummesson. 2011. Pemasaran Jasa. $7^{\text {thEdition. Erlangga. }}$ Jakarta.

Magdalena, M., S. Arto, dan R. Ginting. 2013. Peningkatan Kualitas Pelayanan dengan Menggunakan Metode Quality Function Deployment (QFD) di Rumah Sakit XYZ.E-Jurnal Teknik Industri FT USU3(2): 31-37.

Margareta, P. A. dan H. C. Wahyuni. 2016. Peningkatan Kualitas Pelatihan di Training Centre melalui Integrasi Metode Service Quality (Servqual) dan Quality Function Deployment (QFD) Study Kasus pada PT. XYZ. Jurnal Teknik Industri 11(3): 33-54.

Mutiara, A., A. Desrianty, dan Yuniar. 2013. Rancangan Meja Dapur Multifungsi Menggunakan Quality Function Deployment (QFD). Jurnal Online Institut Teknologi Nasional 1(2): 159-169.

Mawarti, F., F. Nuraini, dan M. H.Thamrin. 2015. Analisis Kualitas Pelayanan Puskesmas terhadap Kepuasan Ibu Hamil di Kota Pangkalpinang.Jurnal Kedokteran dan Kesehatan 3(1):363-371.

Mohsan, F., M. M. Nawaz, M. S. Khan, Z. Shaukat, dan N. Aslam. 2011. Impact of Customer Satisfaction on Customer Loyalty and Intentions to Switch: Evidence from Banking Sector of Pakistan. International Journal of Business and Social Science 2(16): 263-270.

Peter, J. P., J. C. Olson, dan K. G. Grunert. 2010. Consumer Behavior and Marketing Strategy. 9th Edition. McGraw-Hill Companies. New York.

Pane, L., A. R. Matondang, dan R. Ginting. 2013.Upaya Peningkatan Kualitas Jasa Kesehatan Menggunakan Integrasi Quality Function Deployment (QFD) dengan
Analytical Hierarchy Process (AHP). EJurnal Teknik Industri FT USU 1(3): 31-36.

Patmawan, D., N. W. Setyanto, dan R. A. Sari. 2015. Analisis Kualitas Jasa Pelayanan Bengkel dengan Mengintegrasikan Metode Service Quality (SERVQUAL) dan Quality Function Deployment (QFD). Jurnal Rekayasa dan Manajemen Sistem Industri 3(1): 85-98.

Rahman, A. dan H. Supomo. 2012. Analisa Kepuasan Pelanggan pada Pekerjaan Reparasi Kapal dengan Metode Quality Function Deployment (QFD). Jurnal Teknik ITS1(1): 297-302.

Simamora, B. 2004. Panduan Riset Perilaku Konsumen. PT. Gramedia Pustaka Utama. Jakarta.

Singgih, M. L., F. Yulismatun, dan R. Immanuel. 2014. Pengembangan Model Integrasi Kano-QFD untuk Mengoptimalkan Kepuasan Konsumen dengan Mempertimbangkan Keterbatasan Dana Pengembangan. Jurnal Manajemen Teknologi 13(2): 188-199.

Siwantara, I. W. 2011. Pengaruh Nilai Pelanggan terhadap Kepuasan dan Loyalitas Pelanggan serta Kinerja Customer Relationship Management (Studi pada Halo Corporate PT. Telkomsel Bali). Jurnal Bisnis dan Kewirausahaan, 7(3): 150161.

Sugiyono. 2010. Metode Penelitian Bisnis. Cetakan Kesepuluh. CV. Alfabeta. Bandung.

Suhendar, E. dan Suroto. 2014. Penerapan Metode Quality Function Deployment (QFD) dalam Upaya Peningkatan Kualitas Pelayanan Akademik pada UB. Jurnal Faktor Exacta 7(4): 372-386.

Sulistyo, H. 2011. Implementasi QFD dalam Meningkatkan Daya Saing Pasar Tradisional. Jurnal Siasat Bisnis 15(2): 157-169.

Suryaningrat, I. B. dan W. Rendra. 2014. Peningkatan Kualitas Produk Tradisional Prol Tape dengan Metode Quality Function Deployment (QFD). Jurnal Agroteknologi 8(2): 131-139. 
Susila, G. P. A. J., N. N. Yulianthini, dan N. L. Henny.2014. Implementasi Quality Function Deployment (QFD) untuk Meningkatkan Layanan Publik di RSUD Kabupaten Buleleng Bali. Jurnal Ilmu Sosial dan Humaniora 3(2): 396-409.

Tampubolon, H. F., A. R. Matondang, dan R. Ginting. 2013. Optimasi Quality Function Deployment (QFD) Berbasis Model Kano untuk Memaksimalkan Kepuasan Konsumen. E-Jurnal Teknik Industri FT USU1(1): 7-15.

Tjiptono, F. 2014. Pemasaran Jasa. Andi. Yogyakarta.

Tutuhatunewa, A. 2010. Aplikasi Metode Quality Function Deployment dalam
Pengembangan Produk Air Minum Kemasan. Jurnal ARIKA 4(1): 11-19.

Utami, E. 2015. Pendekatan Model Kano pada Quality Function Deployment untuk Perbaikan Kualitas Kegiatan Belajar Mengajar. Jurnal Ilmiah Teknik Industri 14(2): 187-195.

Yin, R. K. 2011. Qualitative Research from Start to Finish. Guilford Publication Inc. New York.

Yulianti, N. dan I. A. Soenandi. 2014. Usaha Peningkatan Pelayanan PT. X Supermarket dengan Metode FuzzyQuality Function Deployment (QFD). Jurnal Ilmiah Teknik Industri 2(1): 21-27 